\title{
Short-term effects of air pollution on respiratory mortality in Ahvaz, Iran
}

\author{
Maryam Dastoorpoor ${ }^{1}$, Narges Khanjani ${ }^{2}$, Abbas Bahrampour ${ }^{3}$, Gholamreza Goudarzi ${ }^{4,5}$, \\ Hamidreza Aghababaeian ${ }^{6}$, Esmaeil Idani*4
}

Received: 20 Jan 2017

Published: 8 Apr 2018

\begin{abstract}
Background: Urban air pollutants may affect respiratory mortality. This study was conducted to investigate this effect in Ahvaz, one of the most polluted cities in the world.

Methods: The impact of 7 major air pollutants including $\mathrm{O}_{3}, \mathrm{PM}_{10}, \mathrm{NO}_{2}, \mathrm{CO}$, and $\mathrm{SO}_{2}$ were evaluated on respiratory mortality in different gender and age groups using a quasi-Poisson, second degree polynomial constrained, distributed lag model, with single and cumulative lag structures adjusted by trend, seasonality, temperature, relative humidity, weekdays, and holiday. Data were analyzed using the dlnm package in R x64 3.2.5 software. Significance level was set at less than 0.05 .

Results: In adjusted models, for each IQR increase of $\mathrm{O}_{3}$ in the total population, the risk ratio (RR) for respiratory deaths in 0 to 14 day lags was, respectively, 1.009 (95\% CI:1.001-1.016) and 1.009 (95\% CI:1.002-1.017), and it was 1.021 (95\% CI: 1.002-1.040) in cumulative 0 to 14- day lags. For $\mathrm{PM}_{10}$, in the total population and in adjusted models after 0 to 14- day lags and in cumulative lags of 0 to 14 for an IQR increase in the mean concentration of $\mathrm{PM}_{10}$, the RR for respiratory deaths increased significantly and was, respectively, 1.027 (95\% CI:1.002-1.051), 1.029 (95\% CI:1.006-1.052), and 1.065 (95\% CI:1.005-1.128). $\mathrm{NO}_{2}$ showed a significant association with respiratory deaths only in the 18 to 60 year- old age group and in 9- day lags ( $R R=1.318,95 \%$ CI:1.002-1.733). Finally, the results showed that for an IQR increase in the mean concentration of $\mathrm{CO}$ and $\mathrm{SO}_{2}$, the adjusted RR for respiratory deaths in 9- day lags in the total population was, respectively, $\mathrm{RR}=1.058$ (95\% CI:1.008-1.111) and 1.126 (95\% CI:1.034-1.220).
\end{abstract}

Conclusion: Air pollution in Ahvaz is probably causing increased respiratory mortality.

Keywords: Short-term effects, Air pollution, Respiratory mortality, Ahvaz

Copyright $@$ Iran University of Medical Sciences

Cite this article as: Dastoorpoor M, Khanjani N, Bahrampour A, Goudarzi Gh, Aghababaeian H, Idani E. Short-term effects of air pollution on respiratory mortality in Ahvaz, Iran. Med J Islam Repub Iran. 2018(8 Apr);32:30. https://doi.org/10.14196/mjiri.32.30

\section{Introduction}

Clean air is considered as a basic requirement of human health and well-being, and air pollution is a major threat to global health (1-3). Air pollution is growing in large cities and is a great concern for the public health $(4,5)$. In the Global Burden of Disease Study in 2012, air pollution is one of the 5 major causes of premature deaths and is responsible for 3.4 million premature deaths worldwide $(4$, 6). Also, it has the first rank among environmental risk factors for adverse health effects (7). Epidemiological studies in different parts of the world have confirmed the

\section{Corresponding author:DrEsmaeilldani,esmaileidani@gmail.com}

1. Neurology Research Center, Kerman University of Medical Sciences, Kerman, Iran. 2.Environmental Health Engineering Research Center, Kerman University of Medical Sciences, Kerman, Iran.

3. Physiology Research Center, Kerman University of Medical Sciences, Kerman, Iran

4. Air Pollution and Respiratory Diseases Research Center, Ahvaz Jundishapur University of Medical Sciences, Ahvaz, Iran.

5. Environmental Technologies Research Center (ETRC), Ahvaz Jundishapur University of Medical Sciences, Ahvaz, Iran.

6. Nursing and Emergency Department, Dezful University of Medical Sciences, Dezful, Iran. acute effects of short- term exposure to air pollution, such as bronchoconstriction and increased asthma symptoms, and chronic effects including chronic lung disease and premature mortality $(8-11)$. These studies provide evidence for the negative effects of urban air pollution on health and a better understanding of biological mechanisms; and in addition to creating an important field of research, they have allowed decision- makers to understand the effects of pollutants and the benefits that can be achieved by control measures (1).

$\uparrow$ What is "already known" in this topic:

Air pollution is growing in large cities and it has become a great concern for the public health. Most studies on the health effects of air pollution have been conducted in North America and Europe. To date, no quantitative study has been conducted on the effect of air quality on respiratory mortality in Ahvaz.

\section{$\rightarrow$ What this article adds:}

The results indicated that $\mathrm{O}_{3}, \mathrm{PM}_{10}, \mathrm{NO}_{2}, \mathrm{CO}$, and $\mathrm{SO}_{2}$ air pollutants in Ahvaz were associated with respiratory mortality on the same day and multi-day lags. 
Most studies on the health effects of air pollution have been conducted in North America and Europe (12-18). However, the effect of air pollution on mortality might be the result of differences in population susceptibility and air pollutants' concentration and components. As a result, there is significant uncertainty in pooled risk estimations (19).

Conducting research in different countries and cities is vital for making local policies. Previous studies have mainly focused on the effects of air pollution on total deaths, and only a limited number of studies have addressed the effect of individual factors, such as age and gender that may be important confounders in the relationship between air pollution and mortality $(20,21)$.

Ahvaz, the capital of Khuzestan province, is Iran's second largest city in area after Tehran, and it is Iran's fifth populated city. The amount of pollution in this city has increased day by day and has become more severe. In 2011, according to the World Health Organization, Ahvaz was the most polluted city in the world, based on the annual average $\mathrm{PM}_{10}$, which was $372 \mu \mathrm{g} / \mathrm{m}^{3}(22,23)$. In Ahvaz, the rate of respiratory problems has increased sharply in recent years, and as of 2011, a new respiratory health crisis occurred in this city, which was repeated in the later years. In 2011, following the first rainfall, the city hospitals faced an increased number of patients with respiratory symptoms, particularly shortness of breath and coughing. This unusual and unexpected number of patients increased gradually, so that within a maximum of 10 hours after the start of a rainfall, 20000 patients in 2013, 10400 patients in 2014, and 26400 patients in 2015 visited the hospitals' emergency departments $(24,25)$.

The most important causes of particulate matter air pollution in Ahvaz are its geographic location and topography, proximity to the Saudi desert, and emerging sources of dust in the neighboring countries. Other sources are transportation and existence of industries including oil, natural gas, and steel that have exposed this city to natural and man-made air pollution $(26,27)$.

To date, no quantitative study has been conducted on the effect of air quality on respiratory mortality in Ahvaz, and the only available knowledge is through studies performed using the Air Q model to estimate the effects of air pollution on respiratory and cardiovascular diseases (2830).

In the present study, the relationship between major air pollutants $\left(\mathrm{O}_{3}, \mathrm{PM}_{10}, \mathrm{NO}_{2}, \mathrm{CO}\right.$ and $\left.\mathrm{SO}_{2}\right)$ and respiratory mortalities on a daily basis was evaluated in different age and gender groups and up to 14-day lags after exposure to air pollutants.

\section{Methods}

\section{Health Outcome Data}

This study was based on data recorded from March 2008 until March 2015 from Ahvaz, Iran. Daily data about mortality due to respiratory diseases in different age and gender subgroups were obtained from Ahvaz City Health Authority.

\section{Exposure Assessment}

Ambient air pollution data were inquired from Khuzestan Province Environmental Protection Agency for 7 major pollutants, which included particulate matter less than $10 \mu \mathrm{m}\left(\mathrm{PM}_{10}\right)$, nitrogen dioxide $\left(\mathrm{NO}_{2}\right)$, carbon monoxide $(\mathrm{CO})$, sulfur dioxide $\left(\mathrm{SO}_{2}\right)$, and ozone $\left(\mathrm{O}_{3}\right) . \mathrm{PM}_{10}$ was the only type of particulate matter recorded at the air quality monitoring stations.

There are 4 air quality monitoring stations in Ahvaz including the Environmental Protection Agency station, Naderi Square station, University Square station, and Meteorological organization station. According to Environmental Protection Agency experts, the air quality monitoring station locations were representative of ambient air quality of the whole city (22).

Data from Ahvaz EPA showed that there is variation across the city with regards to the concentration of air pollutants based on hour, day, week, and month, but not based on location (23).

Studies $(31,32)$ have shown that meteorological parameters affect respiratory mortality; thus, to control their confounding effect, data on meteorological parameters, such as average temperature and relative humidity, were inquired on a daily basis from the Bureau of Meteorology of Khuzestan Province. The daily data of respiratory mortality was matched with pollutants and meteorological parameters.

\section{City Presentation}

Ahvaz, with an area of 8152 square kilometers, is the capital city of Khuzestan province and is located between $31^{\circ} 20^{\prime} \mathrm{N}$ and $48^{\circ} 40^{\prime} \mathrm{E}$ (28). According to 2011 census, 286032 households and 1056589 people live in Ahvaz (33) (Fig. 1).

\section{Statistical Analysis}

The association between respiratory mortalities with mean daily air pollution was analyzed using a quasiPoisson, second degree polynomial constrained, distributed lag model using single and cumulative lag structures, adjusted by trend, seasonality, temperature, relative humidity, weekdays, and holidays. Single day lag effects of air pollutant exposure were estimated for 1 to 14- day lags. Distributed lag models (DLM) with 0 to 14- day lags

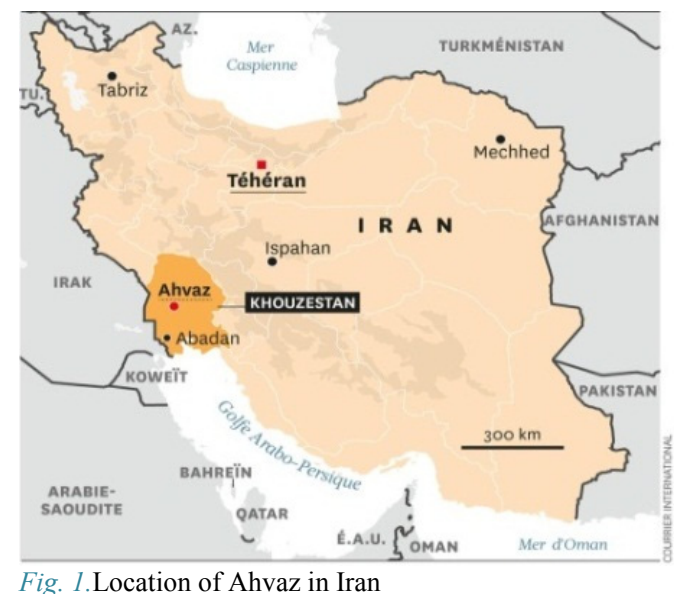

Fig. 1.Location of Ahvaz in Iran 
were also used to estimate respiratory mortalities with potential cumulative exposure effects. Analysis was done for total deaths, age, and gender subgroups. Previous research $(8,9,34)$ has shown that the effects of air pollutants are not the same in different age and sex groups.

Analyses were performed using the dlnm package in $\mathrm{R}$ x64 3.2.5 software. We calculated lags only up to 14 days, as we were looking for the more acute effects of air pollution on respiratory mortalities. Significance level was set at less than 0.05 .

\section{Results}

The total number of respiratory mortalities between March 2008 and March 2015 in Ahvaz (2557 days) was 1824 cases, with an average of almost 22 deaths per month. The number of respiratory mortality was higher in males and in the group older than 60 years compared to females, 18 to 60 years' age group, and younger than 18 group (Table 1). Respiratory disease mortality in all people, males, and over 60 year-old group showed a significant increase from 2009 (Fig. 2).

The most major air pollutants in Ahvaz were particulate matter smaller than 10 micrometers; moreover, the daily average of $\mathrm{PM}_{10}$ during 2008 and 2015 was $237.2 \mu \mathrm{g} / \mathrm{m}^{3}$, ranging from 25.0 to 4498.0 . The average rate of this pol- lutant has been higher than the acceptable level of 100 $\mu \mathrm{g} / \mathrm{m}^{3}$. Other descriptive statistics about respiratory mortality, air pollution, and climate parameters are presented in Table 1.

The results of single lag and cumulative lag models on the relationship between respiratory death and air pollutants in the total population and in gender and age subgroups for each IQR increase in average pollutant concentration are presented in Tables 2 and 3 and Fig. 3.

In the adjusted models in the total population for each IQR increase of $\mathrm{O}_{3}$, which was about $72.7 \mu \mathrm{g} / \mathrm{m}^{3}$, the risk ratio for respiratory deaths in 0 to 14- day lags was 1.009 (95\% CI:1.001-1.016) and 1.009 (95\% CI:1.002-1.017), respectively; and in cumulative 0 to 14- day lags was 1.021 (95\% CI: 1.002-1.040), indicating that for a IQR increase in the mean concentration of $\mathrm{O}_{3}$, the risk of respiratory deaths increases by $2 \%$ up to 14 days after exposure to $\mathrm{O}_{3}$.

$\mathrm{O}_{3}$ also showed a significant relationship in population subgroups. In the adjusted models in 8- day lags for an IQR increase in the mean concentration of $\mathrm{O}_{3}$, the risk ratio for respiratory deaths significantly increased in females $(\mathrm{RR}=1.019,95 \%$ CI:1.007-1.030) and in those over the age of $60(\mathrm{RR}=1.011,95 \% \mathrm{CI}: 1.001-1.022)$.

Table 1.Number of respiratory deaths and descriptive indices of air pollutants and climate factors in Ahvaz from March 2008 to March 2015

\begin{tabular}{|c|c|c|c|c|c|c|c|}
\hline \multirow{2}{*}{$\begin{array}{l}\text { Number of } \\
\text { respiratory deaths }\end{array}$} & $>60$ years $(\%)$ & 18 to 60 & $<18$ years & Males (\%) & Females $(\%)$ & \multicolumn{2}{|c|}{ Overall (\%) } \\
\hline & $1180.0(64.7 \%)$ & $448.0(24.6 \%)$ & $196.0(10.7 \%)$ & $1106.0(60.6 \%)$ & $718.0(39.4 \%)$ & \multicolumn{2}{|c|}{$1824.0(100 \%)$} \\
\hline $\begin{array}{l}\text { Variable } \\
\text { (Mean per day) }\end{array}$ & Mean \pm SE & Minimum & Maximum & $25 \%$ quartile & Median & $75 \%$ quartile & $\begin{array}{c}\text { Interquartile } \\
\text { range }\end{array}$ \\
\hline $\mathrm{O}_{3}(\mathrm{ppb})$ & $24.2 \pm 18.1$ & 3.0 & 661.0 & 18.0 & 22.0 & 28.0 & 10.0 \\
\hline $\mathrm{PM}_{10}\left(\mu \mathrm{g} / \mathrm{m}^{3}\right)$ & $237.2 \pm 289.8$ & 25.0 & 4498.0 & 119.2 & 162.5 & 249.5 & 130.3 \\
\hline $\mathrm{NO}_{2}(\mathrm{ppb})$ & $26.4 \pm 27.6$ & 1.0 & 720.0 & 12.0 & 21.0 & 34.0 & 22.0 \\
\hline $\mathrm{CO}(\mathrm{ppb})$ & $1141.3 \pm 1244.3$ & 100.0 & 11900.0 & 500.0 & 900.0 & 1300.0 & 800.0 \\
\hline $\mathrm{SO}_{2}(\mathrm{ppb})$ & $18.6 \pm 30.6$ & 1.0 & 1416.0 & 10.0 & 17.0 & 24.0 & 14.0 \\
\hline Temperature $\left({ }^{\circ} \mathrm{C}\right)$ & $26.7 \pm 9.1$ & 11.6 & 39.5 & 25.5 & 27.1 & 27.8 & 2.3 \\
\hline Relative humidity (\%) & $43.1 \pm 15.8$ & 19.0 & 77.0 & 40.3 & 41.0 & 45.9 & 5.6 \\
\hline Total rainfall (mm) & $14.0 \pm 23.4$ & 0.0 & 113.0 & 11.8 & 2.4 & 16.2 & 4.4 \\
\hline Total sunshine (hours) & $256.4 \pm 62.6$ & 144.0 & 374.0 & 247.7 & 253.2 & 263.9 & 16.2 \\
\hline Total evaporation (mm) & $264.7 \pm 161.3$ & 41.0 & 541.0 & 237.8 & 255.2 & 291.8 & 54.0 \\
\hline Wind speed $(\mathrm{m} / \mathrm{s})$ & $11.5 \pm 5.3$ & 7.0 & 44.0 & 11.4 & 10.0 & 11.9 & 0.5 \\
\hline Wind direction $\left({ }^{\circ}\right)$ & $227.2 \pm 82.6$ & 42.0 & 350.0 & 213.4 & 270.0 & 236.2 & 22.8 \\
\hline
\end{tabular}

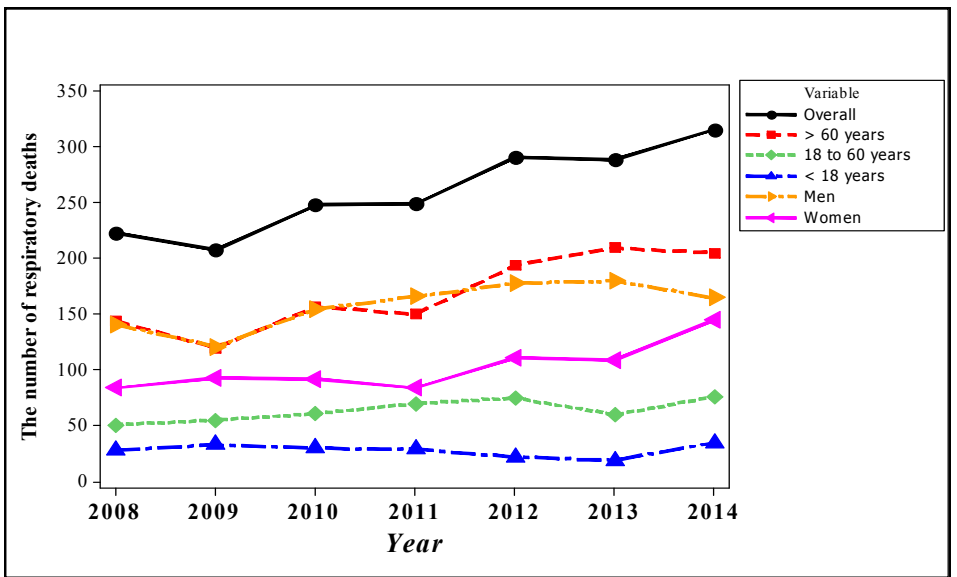

Fig. 2.The trend of respiratory disease mortality from March 2008 to March 2015 
Table 2.Risk ratio $(95 \% \mathrm{CIs})$ of respiratory deaths for each IQR increase in pollutants in single and cumulative lag structure models (overall, Males, females)

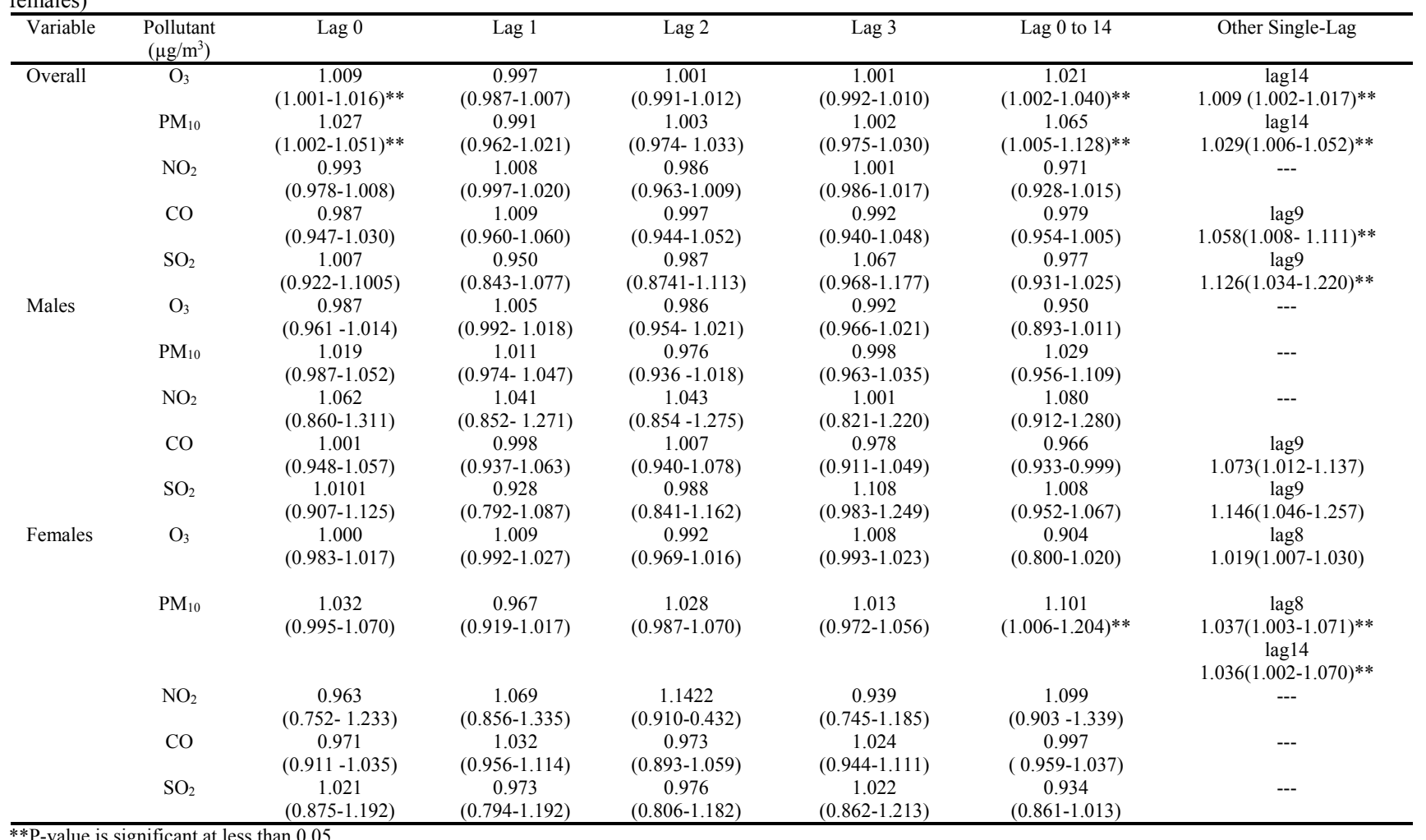

Based on the results for $\mathrm{PM}_{10}$ in the total population and in adjusted models in 0 to 14- day lags and in cumulative lags of 0 to 14, for an IQR increase in the mean concentration of $\mathrm{PM}_{10}$, which was about $237.3 \mu \mathrm{g} / \mathrm{m}^{3}$, the risk ratio for respiratory deaths increased significantly and was, respectively, 1.027 (95\% CI: 1.002-1.051), 1.029 (95\% CI: 1.006-1.052), and 1.065 (95\% CI:1.005-1.128). Also, in females, $\mathrm{PM}_{10}$ showed significant associations with respiratory deaths in 8 - day $(\mathrm{RR}=1.037,95 \% \mathrm{CI}=1.003$ -
$1.071), 14-$ day $(\mathrm{RR}=1.036,95 \% \mathrm{CI}=1.002-1.070)$, and cumulative 0 to 14 day lags $(\mathrm{RR}=1.101,95 \% \mathrm{CI}=1.006$ 1.204). Moreover, $\mathrm{PM}_{10}$ showed significant associations with respiratory deaths in under 18 age group in 4- day lags $(\mathrm{RR}=1.070,95 \% \mathrm{CI}=1.004-1.140)$, in 18 to 60 age group in 5- day lags $(\mathrm{RR}=1.044,95 \% \mathrm{CI}=1.002$ 1.088 ), and in over 60 age group in 14- day lags.

The $\mathrm{NO}_{2}$ pollutant showed a significant association with respiratory deaths only in 18 to 60 age group and in 9- day

Table 3.Risk ratio ( $95 \%$ CIs) of respiratory deaths for each IQR increase in pollutant in single and cumulative lag structure $(<18$ years, 18 to 60 years, $>60$ years)

\begin{tabular}{|c|c|c|c|c|c|c|c|}
\hline Variable & $\begin{array}{c}\text { Pollutant } \\
\left(\mu \mathrm{g} / \mathrm{m}^{3}\right)\end{array}$ & Lag 0 & Lag 1 & $\operatorname{Lag} 2$ & Lag 3 & Lag 0 to 14 & Other single-lag \\
\hline \multirow[t]{5}{*}{$<18$ years } & $\mathrm{O}_{3}$ & $\begin{array}{c}0.995(0.917- \\
1.078)\end{array}$ & $\begin{array}{c}0.993(0.913- \\
1.080)\end{array}$ & $\begin{array}{c}0.988(0.932- \\
1.049)\end{array}$ & $\begin{array}{c}0.993(0.936- \\
1.053)\end{array}$ & $\begin{array}{c}0.872 \\
(0.721-1.056)\end{array}$ & --- \\
\hline & $\mathrm{PM}_{10}$ & $\begin{array}{c}1.006(0.925- \\
1.094)\end{array}$ & $\begin{array}{c}0.983(0.890- \\
1.085)\end{array}$ & $\begin{array}{c}1.029(0.941- \\
1.126)\end{array}$ & $\begin{array}{c}0.972(0.876- \\
1.079)\end{array}$ & $\begin{array}{c}0.935 \\
(0.774-1.128)\end{array}$ & $\begin{array}{c}\operatorname{lag} 4 \\
1.070(1.004-1.140)^{* *}\end{array}$ \\
\hline & $\mathrm{NO}_{2}$ & $\begin{array}{c}1.450 \\
(0.943-2.230)\end{array}$ & $\begin{array}{c}0.962 \\
(0.614-1.509)\end{array}$ & $\begin{array}{c}1.356 \\
(0.849-2.165)\end{array}$ & $\begin{array}{c}0.692 \\
(0.414-1.158\end{array}$ & $\begin{array}{c}0.926 \\
(0.626-1.371)\end{array}$ & --- \\
\hline & $\mathrm{CO}$ & $\begin{array}{c}0.986 \\
(0.886-1.098)\end{array}$ & $\begin{array}{c}1.027 \\
(0.904-1.1667)\end{array}$ & $\begin{array}{c}0.950 \\
(0.817-1.105)\end{array}$ & $\begin{array}{c}0.960 \\
(0.836-1.103)\end{array}$ & $\begin{array}{c}1.071 \\
(1.007-1.140)\end{array}$ & --- \\
\hline & $\mathrm{SO}_{2}$ & $\begin{array}{c}1.102 \\
(0.960-1.265)\end{array}$ & $\begin{array}{c}0.822 \\
(0.636-1.064)\end{array}$ & $\begin{array}{c}0.987 \\
(0.767-1.272)\end{array}$ & $\begin{array}{c}1.067 \\
(0.872-1.306)\end{array}$ & $\begin{array}{c}0.953(0.862- \\
1.054)\end{array}$ & --- \\
\hline \multirow[t]{5}{*}{18 to 60 years } & $\mathrm{O}_{3}$ & $\begin{array}{c}0.994 \\
(0.958-1.032)\end{array}$ & $\begin{array}{c}0.994 \\
(0.942-1.046)\end{array}$ & $\begin{array}{c}0.976 \\
(0.909-1.050)\end{array}$ & $\begin{array}{c}1.014 \\
(0.998-1.033)\end{array}$ & $\begin{array}{c}0.866 \\
(0.731-1.026)\end{array}$ & --- \\
\hline & $\mathrm{PM}_{10}$ & $\begin{array}{c}1.033 \\
(0.985-1.083)\end{array}$ & $\begin{array}{c}0.986 \\
(0.929-1.045)\end{array}$ & $\begin{array}{c}0.996 \\
(0.935-1.060)\end{array}$ & $\begin{array}{c}1.023 \\
(0.973-1.077)\end{array}$ & $\begin{array}{c}1.105 \\
(0.989-1.234)\end{array}$ & $\begin{array}{c}\operatorname{lag} 5 \\
1.044(1.002-1.088)^{* *}\end{array}$ \\
\hline & $\mathrm{NO}_{2}$ & $\begin{array}{c}0.963 \\
(0.685-1.354)\end{array}$ & $\begin{array}{c}1.031 \\
(0.750-1.418)\end{array}$ & $\begin{array}{c}1.064 \\
(0.781-1.448)\end{array}$ & $\begin{array}{c}0.940 \\
(0.690-1.281)\end{array}$ & $\begin{array}{c}1.068 \\
(0.820-1.392)\end{array}$ & $\begin{array}{c}\text { lag9 } \\
1.318(1.002-1.733)^{* *}\end{array}$ \\
\hline & $\mathrm{CO}$ & $\begin{array}{c}0.932 \\
(0.845-0.027)\end{array}$ & $\begin{array}{c}1.028 \\
(0.926-1.141)\end{array}$ & $\begin{array}{c}1.027 \\
(0.916-1.151)\end{array}$ & $\begin{array}{c}0.965 \\
(0.863-1.079)\end{array}$ & $\begin{array}{c}0.981 \\
(0.930-1.035)\end{array}$ & --- \\
\hline & $\mathrm{SO}_{2}$ & $\begin{array}{c}1.102 \\
(0.960-1.265)\end{array}$ & $\begin{array}{c}0.822 \\
(0.636-1.063)\end{array}$ & $\begin{array}{c}0.988 \\
(0.767-1.272)\end{array}$ & $\begin{array}{c}1.068 \\
(0.872-1.306)\end{array}$ & $\begin{array}{c}0.953 \\
(0.862-1.054)\end{array}$ & --- \\
\hline
\end{tabular}




\begin{tabular}{|c|c|c|c|c|c|c|c|}
\hline \multirow{4}{*}{$>60$ years } & $\mathrm{O}_{3}$ & $\begin{array}{c}0.996 \\
(0.982-1.009)\end{array}$ & $\begin{array}{c}1.010 \\
(0.998-1.021)\end{array}$ & $\begin{array}{c}0.990 \\
(0.969-1.012)\end{array}$ & $\begin{array}{c}0.991 \\
(0.969-1.012)\end{array}$ & $\begin{array}{c}0.978 \\
(0.932-1.026)\end{array}$ & $\begin{array}{c}\text { lag8 } \\
1.011(1.001-1.022)^{* *}\end{array}$ \\
\hline & $\mathrm{PM}_{10}$ & $\begin{array}{c}1.025 \\
(0.994-1.057)\end{array}$ & $\begin{array}{c}0.994 \\
(0.956-1.033)\end{array}$ & $\begin{array}{c}1.003 \\
(0.967-1.040)\end{array}$ & $\begin{array}{c}0.998 \\
(0.963-1.034)\end{array}$ & $\begin{array}{c}1.060 \\
(0.984-1.141)\end{array}$ & $\begin{array}{c}\operatorname{lag} 14 \\
1.037(1.009-1.066)^{* *}\end{array}$ \\
\hline & $\mathrm{NO}_{2}$ & $\begin{array}{c}1.002 \\
(0.815-1.232)\end{array}$ & $\begin{array}{c}1.060 \\
(0.879-1.279)\end{array}$ & $\begin{array}{c}1.086 \\
(0.900-1.310)\end{array}$ & $\begin{array}{c}1.034 \\
(0.858-1.245)\end{array}$ & $\begin{array}{c}1.130 \\
(0.957-1.333)\end{array}$ & --- \\
\hline & $\mathrm{SO}_{2}$ & $\begin{array}{c}1.007 \\
(0.955-1.062) \\
0.968 \\
(0.856-1.093)\end{array}$ & $\begin{array}{c}1.002 \\
(0.939-1.068) \\
0.993 \\
(0.855-1.156)\end{array}$ & $\begin{array}{c}0.996 \\
(0.931-1.067) \\
0.996 \\
(0.861-1.152)\end{array}$ & $\begin{array}{c}1.012 \\
(0.9432-1.085) \\
1.074 \\
(0.951-1.213)\end{array}$ & $\begin{array}{c}0.946 \\
(0.912-0.982) \\
0.990 \\
(0.933-1.050)\end{array}$ & $\begin{array}{c}\text { lag9 } \\
1.067(1.004-1.138)^{* *} \\
\text { lag9 } \\
1.165(1.063-1.276)^{* *}\end{array}$ \\
\hline
\end{tabular}
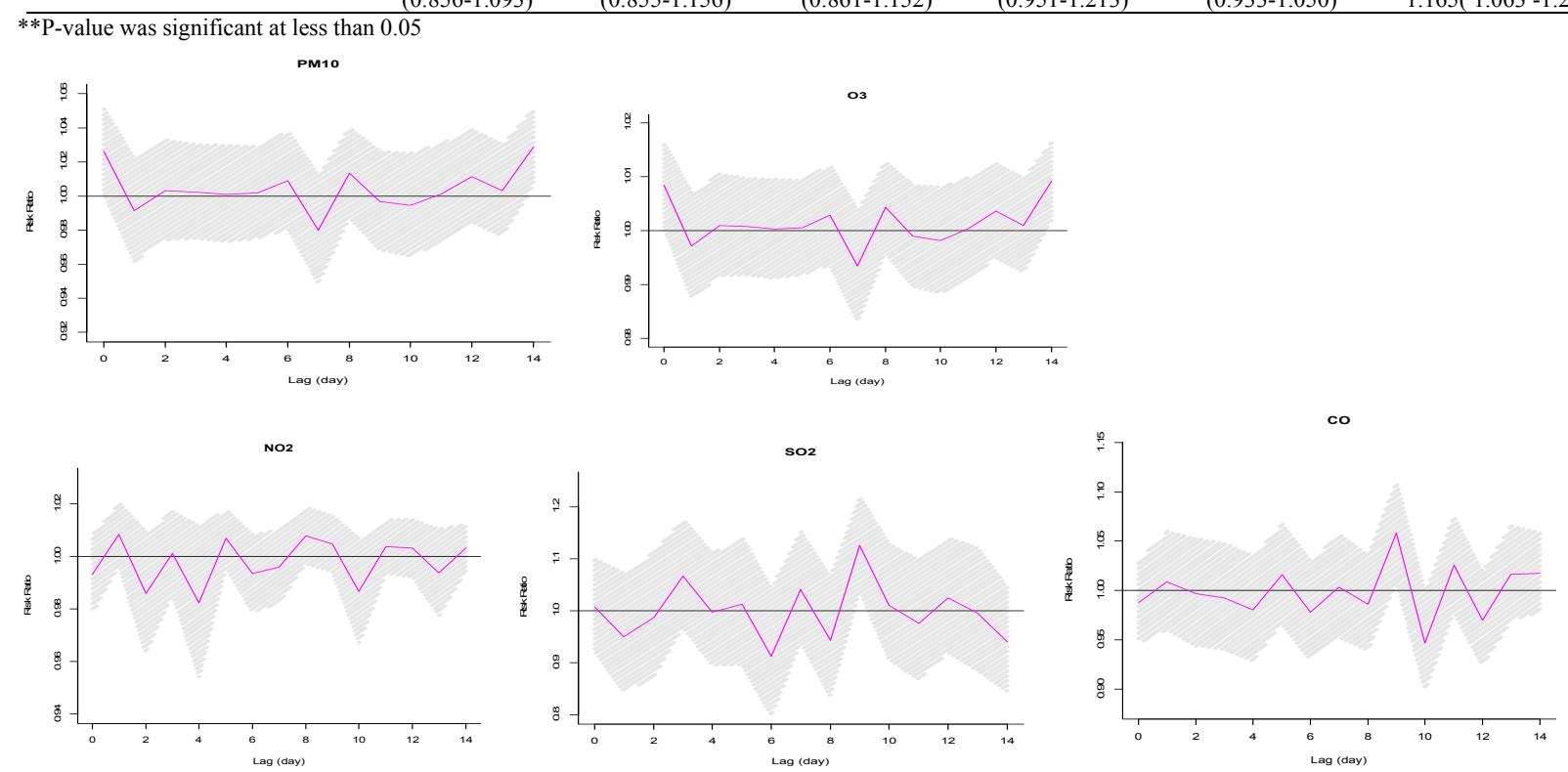

Fig. 3.Risk ratio (95\% CIs) of respiratory deaths for each IQR increase in pollutant in single 0 to 14 - day lag in the total population

lags; and for an IQR increase in the mean concentration of $\mathrm{NO}_{2}$, which was about $61.3 \mu \mathrm{g} / \mathrm{m}^{3}$, RR was $1.318(95 \% \mathrm{CI}$ : 1.002-1.733).

The results indicated that for an IQR increase (about $1.12 \mu \mathrm{g} / \mathrm{m}^{3}$ ) in the mean concentration of $\mathrm{CO}$, the adjusted RR for respiratory deaths in 9- day lags in the total population was $1.058(95 \% \mathrm{CI}: 1.008-1.111)$, it was 1.073 (95\% CI:1.012-1.137) in males, and $1.067(95 \%$ CI:1.004-1.138) in over 60 age group. Also, the association between the mean $\mathrm{CO}$ concentration and respiratory deaths in cumulative 0 to 14 lags was significant in the population under 18 years $(\mathrm{RR}=1.071,95 \% \mathrm{CI}$ : 1.007 1.140).

In the adjusted model, in 9- day lags, for an IQR increase in the concentration of $\mathrm{SO}_{2}$, which was about $62.2 \mu \mathrm{g} / \mathrm{m}^{3}$, the adjusted RR for respiratory deaths in the total population, males, and the over 60 age group was, respectively, 1.126 (95\% CI: 1.034-1.220), 1.146 (95\% CI: $1.046-1.257)$, and 1.165 (95\% CI: $1.063-1.276)$. (Tables 2, 3, and Fig. 3).

\section{Discussion}

Air pollution is one of the important problems of large industrial cities. In Iran, there is evidence about the relationship between air pollutants and deaths from cardiovascular and respiratory diseases in Kerman, Shiraz, and Arak (8, 34-36). However, no similar study was conducted in Ahvaz. The present study was conducted to estimate the acute effects of air pollutants $\left(\mathrm{O}_{3}, \mathrm{PM}_{10}, \mathrm{NO}_{2}, \mathrm{CO}\right.$, and $\mathrm{SO}_{2}$ ) on respiratory mortalities.

The major air pollutant in Ahvaz was particulate matter smaller than 10 micrometers, and the daily average of $\mathrm{PM}_{10}$ during 2008 and 2015 was higher than the acceptable level. Dust storms are one of the main natural hazards that have affected the West and Southwest of Iran and Ahvaz in Khuzestan province in recent years; and besides numerous social and economic problems, dust storms have jeopardized people's health (37). Several factors are involved in this regard, the most important of which are bordering Khuzestan province with Iraq and the increased number of dust days and reduced precipitation in Iraq. Also, Turkey and Syria built dams on the Tigris and Euphrates in 1977, which led to drying Hvralzym Marshes and Shadegan wetlands in Ahvaz (38). Actions, such as watering the Hvralzym Marshes and Shadegan wetlands and their mulching, have reduced the amount of the dust in recent years (37).

The present study revealed a significant positive relationship between the concentrations of ambient air $\mathrm{O}_{3}$ and respiratory deaths in the total population in 0 and 14- day lags and cumulative 0 to 14 day lags. $\mathrm{O}_{3}$ also showed a significant positive relationship with respiratory deaths in population subgroups, in females, and in over 60 age group on 8- day lags.

$\mathrm{O}_{3}$ was related to death due to respiratory diseases in other studies as well. In a study done in Taiwan, a signifi- 
cant association was observed between daily respiratory disease mortality and $\mathrm{O}_{3}$ among people over 65 years and all ages in the winter. Also, results showed that this pollutant was related to daily respiratory disease mortality among people over 65 years only in the summer (39). In Lipsett et al.'s study in California, the relationship between $\mathrm{O}_{3}$ and non-cancerous respiratory mortality was significant as well (40).

However, some studies have reported non-significant relationships between $\mathrm{O}_{3}$ and respiratory mortality. Jerrett et al. reported a positive correlation between respiratory mortality and long-term exposure to $\mathrm{O}_{3}$ throughout California. Nonetheless, after geographical analysis in Southern $(\mathrm{RR}=1.01,95 \% \mathrm{CI}: 0.96$ to 1.07$)$, Northeast $(\mathrm{RR}=$ 0.99, 95\% CI: 0.92 to 1.07$)$, and Southeastern ( $R R=1.12$, 95\% CI 1.05-1.19) California, no relationship was found between $\mathrm{O}_{3}$ and respiratory mortality (41). In a study in China, after adjusting for other pollutants, $\mathrm{O}_{3}$ had no significant relationship with mortality due to respiratory diseases (42).

The scientific aspects of ozone's adverse effects are still under question. Issues such as its acute or chronic effects, confounders, or its interaction with climate variables and other pollutants are still not well understood (43). Nevertheless, its adverse effects are important because nowadays the levels of ozone are much higher than the preindustrial times (43).

In this study, $\mathrm{PM}_{10}$ showed a significant relationship with respiratory deaths in some lags and some subgroups. Similar to these results in New Zealand, in an adjusted statistical model, a significant association was found between increased mean $\mathrm{PM}_{10}$ levels and respiratory deaths (excluding lung cancer) (44). In a study conducted in California among never smokers, both $\mathrm{PM}_{10}$ and $\mathrm{PM}_{2.5}$ were related to non-cancerous respiratory deaths (40). In another study done in California on both genders, there was a significant association between $\mathrm{PM}_{10}$ and respiratory mortality (45). In the city of Wuhan in China, each $10 \mathrm{mg}$ increase in the daily concentration of $\mathrm{PM}_{10}$ (at lag 0 ) was related to $71 \%$ increase in respiratory mortality (46). Jonidi et al. also showed a weak but significant association between $\mathrm{PM}_{10}$ and respiratory and cardiac deaths in Tehran (47). Also, in a study in Kerman, Iran, after adjusting for temperature and humidity, there was a significant direct association between male respiratory death and $\mathrm{PM}_{10}$, but this significant relationship was not seen among females (9). Braga et al.'s study (2001) conducted in 10 cities in the US, found that in respiratory deaths, exposure to $\mathrm{PM}_{10}$ after a one day lag (for death from pneumonia) and a 2-day lag (for death from COPD) had a greater impact than exposure on the same day. However, cardiovascular deaths were more affected by $\mathrm{PM}_{10}$ concentrations on the same day (48). Another study by Kim et al. (2003) found no association between exposure to $\mathrm{PM}_{10}$ and increase in respiratory mortalities caused by COPD on the same day, but this relationship was significant in the lagged model (increased mortality $=12.2 \%, 95 \% \mathrm{CI}: 2.5 \%$ - 22.9\%) (49). Zeka et al. (2005) showed that deaths from respiratory diseases were associated with concentration of $\mathrm{PM}_{10}$ on the previous day (\% increase in respiratory mor- talities was related to one unit increase in the concentration of $\mathrm{PM}_{10}(0.52 \%, 95 \% \mathrm{CI}: 0.15 \%-0.89 \%$. $), 2$ days before $(0.51 \%$, CI $95 \%$ : $0.16 \%-0.86 \%)$, and 3 days before $(0.87 \%$, CI $95 \%: 0.38 \%-1.36 \%)$. These researchers stated that considering only one time lag leads to underestimation of the effects of $\mathrm{PM}_{10}$ on all mortalities and cardiopulmonary mortality (50). Analitis et al. (2005) showed that for every $10 \mu \mathrm{g} / \mathrm{m}^{3}$ increase in $\mathrm{PM}_{10}$ in the 0 and $1 \mathrm{lag}$ time, a $0.58 \%$ increase in respiratory deaths was seen (CI 95\%: $0.21 \%-0.95 \%$ ) (12). The majority of researchers in this field believe that cardiovascular and respiratory mortality lag patterns are different, but it seems that like cardiovascular mortalities, they are more influenced by pollutants on the same day, while respiratory deaths are more affected by pollutants in earlier days $(48,51,52)$.

In this study, a strong significant relationship was found between the mean concentration of $\mathrm{NO}_{2}$ and respiratory deaths in the 18 to 60 age group and in 9- day lags. A study by Cesaroni et al. (2013) on those older than 30 in Rome showed a significant positive relationship between respiratory mortality and $\mathrm{NO}_{2}$ (Hazard Ratio: 1.03, CI 95\%: 1.00-1.06) after adjustment for confounding variables including gender, marital status, place of birth, education, and social/economic status (53). In another study by Beelen et al. (2008) using data from the Netherlands diet and cancer Cohort, a significant positive correlation was observed between $\mathrm{NO}_{2}$ pollution and respiratory mortality; and after adjustment for age, gender, smoking habits, and socioeconomic status, for each $10 \mu \mathrm{g} / \mathrm{m} 3$ increase in the concentration of $\mathrm{NO}_{\mathrm{X}}$, the relative risk for respiratory mortality was 1.37 (95\% CI: 1.00-1.87)(54). Gehring et al. (2006) conducted a study on 4800 (50-59 year- old) females using the Cox's proportional hazards model adjusted for smoking and socioeconomic status, and they reported a positive relationship between increase in $\mathrm{NO}_{2}$ concentration and death from cardiopulmonary disease (Hazard Ratio: $1.57,95 \%$ CI: 1.23 - 2.00) as well (55). Also, in a cohort study by Heinrich et al. (2012) on 4800 (55 yearold) females in Germany, the adjusted results showed that an increase of $16 \mu \mathrm{g} / \mathrm{m}^{3}$ in the concentration of $\mathrm{NO}_{2}$ is associated with increased all- cause mortality (Hazard Ratio: 1.18, 95\% CI: 1.07- 1.30) from cardiopulmonary disease (Hazard Ratio: 1.55, 95\% CI: 1.30 - 1.84) (56). Finally, in Dong et al. (2011) in Shenyang, China (57), Yorifuji et al. (2010) in Shizuoka, Japan (58), and Filleul et al. (2005) in 7 cities in France (59), the hazard ratio for every 10 micrograms per cubic meter increase in $\mathrm{NO}_{2}$ for respiratory related deaths was $2.97(95 \% \mathrm{CI}: 2.69-3.27)$, 1.19 (95\% CI: 1.02-1.38), and 1.27 (95\% CI: 1.04-1.56), respectively.

Despite the laboratory, clinical, and epidemiological studies, the health effects of exposure to $\mathrm{NO}_{2}$ in humans are not understood well. $\mathrm{NO}_{2}$ is a hardly water-soluble, highly reactive, and nitrogen-centered gas with free radicals that resides in the lung tissue. $\mathrm{NO}_{2}$ penetrates the respiratory system, but studies have shown that terminal bronchioles are the main place for their reaction. The main destructive mechanism of $\mathrm{NO}_{2}$ in the respiratory tract is lipid peroxidation in cell membranes and involvement in various free radical reactions that effect the cell structure 
and function (60). $\mathrm{NO}_{2}$ causes inflammation of the airways, particularly the terminal bronchioles (61). It has been shown in human studies that the main effect of $\mathrm{NO}_{2}$ in inducing airway reactivity was in concentrations $\geq 1800$ $\mu \mathrm{g} / \mathrm{m}^{3}$ in healthy individuals and in concentration of 200 to $500 \mu \mathrm{g} / \mathrm{m}^{3}$ in patients with asthma (62) and patients with chronic obstructive pulmonary disease (63). Also, $\mathrm{NO}_{2}$ has a reinforcing effect on asthmatic response to allergens. Evidence suggests that 15 to 30 minutes exposure to $500 \mu \mathrm{g} / \mathrm{m}^{3} \mathrm{NO}_{2}$ activates asthmatic reactions (15). Some studies suggest that 15 minutes of exposure to 500 $\mu \mathrm{g} / \mathrm{m}^{3} \mathrm{NO}_{2}$ in high traffic locations could cause inflammatory allergic reactions in airways without causing symptoms or lung defects (64). $\mathrm{NO}_{2}$ in concentrations present in the atmosphere are potentially irritating and associated with chronic obstructive pulmonary diseases. It also increases airway reaction in asthmatics and can cause severe acute respiratory symptoms such as cough, chest pain, shortness of breath, and bronchopneumonia (65). Also, toxicological evidence suggest that increased sensitivity to infection, functional impairment of the airways, and worsening health status of people with chronic respiratory conditions are among the potential health impacts of $\mathrm{NO}_{2}(15)$.

With regards to CO, this study showed that this pollutant was related to respiratory deaths after 9- day lags in the total population, in males, and in older than 60 age group. Also, in the population under 18, there was a significant association between the mean of $\mathrm{CO}$ and respiratory deaths in the cumulative 0 to 14- day lags. In a study done in Tehran, $\mathrm{CO}$ was directly related to respiratory deaths and the correlation was about 0.7 (66). In another study from Tehran, in the months that $\mathrm{CO}$ increased, the rate of respiratory mortality in children under 12 years increased as well(67). In a study from Shiraz, Iran, the results of multivariate analysis showed that $\mathrm{CO}$ is directly related to respiratory death in the total population, males, females, and those aged 18 to 60 years (8).

Finally, the present study found a significant positive relationship between the concentrations of ambient air $\mathrm{SO}_{2}$ and respiratory deaths in the total population, males, and older than 60 age group in 9- day lags. Similar to this, in Wong et al.'s study in China, $\mathrm{SO}_{2}$ was directly and significantly related to respiratory death (42). In another study from California, $\mathrm{SO}_{2}$ showed a strong relationship with increased mortality from lung cancer in both genders (45). In a study from Kerman, Iran, after adjusting for temperature and humidity, a significant association was observed between increased respiratory mortality among males (but not females) and ambient air $\mathrm{SO}_{2}(9)$. However, several studies that have shown a non-significant association between $\mathrm{SO} 2$ and respiratory mortality, such as a study from Beijing (68). In a study on the long-term effects of air pollution on adult mortality in 18 areas in 7 cities in France, the relationship between $\mathrm{SO}_{2}$ and cardiopulmonary disease was not significant (59), and in the study conducted by Liang in Taiwan, $\mathrm{SO}_{2}$ had no significant association with respiratory mortality (39).

Several mechanisms explain the effects of air pollution on the respiratory system. The most acceptable and basic explanation is that in exposure of the respiratory epithelium to air pollutants, high concentrations of oxidants and pro-oxidants in these pollutants form oxygen and nitrogen- free radicals that cause oxidative stress in the respiratory system. In other words, an increase in free radicals initiates an inflammatory response and release of inflammatory cells and mediators (cytokines, chemokines, and adhesion molecules) to the circulatory system, which creates a subclinical inflammation that not only has a negative impact on the respiratory system, but also causes systemic effects $(2,69,70)$.

One of the limitations of this study was that exposure measurement was done by air pollution stations that do not accurately represent exposure at the individual level. Nevertheless, this method is the most practical and affordable method to measure exposure in air pollution studies (71). Another limitation of this study was lack of socioeconomic information on the deceased, which prevented us from adjusting this variable.

\section{Conclusion}

Air pollutants in Ahvaz were associated with respiratory mortality on the same day and multi-day lags. Due to the increasing trend of respiratory deaths in this city, it is necessary to implement interventions to reduce air pollution sources and adopt policies to reduce exposure to air pollution in Ahvaz.

\section{Acknowledgements}

The authors thank the Deputy of Health at Jundishapur University of Medical Sciences, the Khuzestan Province Environmental Protection Agency, and Ahvaz Bureau of Meteorology. This project was approved by the Neurology Research Center of Kerman University of Medical Sciences and was funded by Kerman University of Medical Sciences, Kerman, Iran.

\section{Financial/support}

This study was funded and supported by Kerman University of Medical Sciences (Ethic Committee No: IR.KMU.REC.1394.377, Grant No: 940590).

\section{Conflict of Interests}

The authors declare that they have no competing interests.

\section{References}

1. Sousa S, Pires J, Martins E, Fortes J, Alvim-Ferraz M, Martins F. Short-term effects of air pollution on respiratory morbidity at Rio de Janeiro-PART I: Air Pollution Assessment. Environ Int. 2012;44:18-25

2. Organization WH. Air quality guidelines: global update 2005 : particulate matter, ozone, nitrogen dioxide, and sulfur dioxide: World Health Organization; 2006.

3. Organization WH. World health statistics 2010: World Health Organization; 2010.

4. Maji S, Ahmed S, Siddiqui WA, Ghosh S. Short term effects of criteria air pollutants on daily mortality in Delhi, India. Atmos Environ. 2017; 150:210-9.

5. Mansouri F, Khanjani N, Pourmousa R. Forecasting ambient air pollutants by time series models in Kerman, Iran. J Sch Public Health Inst Public Health Res. 2013;11(2):75-86. 
6. Organization WH. Burden of disease from Ambient Air Pollution for 2012. World Health Organization. 2014.

7. Hänninen O, Knol AB, Jantunen M, Lim T-A, Conrad A, Rappolder $\mathrm{M}$, et al. Environmental burden of disease in Europe: assessing nine risk factors in six countries. 2015.

8. Dadbakhsh M, Khanjani N, Bahrampour A. Death from Respiratory Diseases and Air Pollutants in Shiraz, Iran (2006-2012). Journal of Environment Pollution and Human Health. 2015;3(1):4-11.

9. Khanjani N, Ranadeh Kalankesh L, Mansouri F. Air Pollution and Respiratory Deaths in Kerman, Iran (from 2006 till 2010). Iran J Epidemiol. 2012;8(3):58-65.

10. Organization WH. The world health report 2002: reducing risks, promoting healthy life: World Health Organization; 2002.

11. Mostofsky E, Schwartz J, Coull BA, Koutrakis P, Wellenius GA, Suh $\mathrm{HH}$, et al. Modeling the association between particle constituents of air pollution and health outcomes. Am J Epidemiol. 2012:kws018.

12. Analitis A, Katsouyanni K, Dimakopoulou K, Samoli E, Nikoloulopoulos AK, Petasakis Y, et al. Short-term effects of ambient particles on cardiovascular and respiratory mortality. Epidemiology. 2006;17(2):230-3.

13. Ballester F, Rodriguez P, Iniguez C, Saez M, Daponte A, Galan I, et al. Air pollution and cardiovascular admissions association in Spain: results within the EMECAS project. J Epidemiol Community Health. 2006;60(4):328-36.

14. Biggeri A, Bellini P, Terracini B. [Meta-analysis of the Italian studies on short-term effects of air pollution--MISA 1996-2002]. Epidemiol Prev. 2003;28(4-5 Suppl):4-100.

15. Samoli E, Aga E, Touloumi G, Nisiotis K, Forsberg B, Lefranc A, et al. Short-term effects of nitrogen dioxide on mortality: an analysis within the APHEA project. Eur Respir J. 2006;27(6):1129-38.

16.Samoli E, Peng R, Ramsay T, Pipikou M, Touloumi G, Dominici F, et al. Acute effects of ambient particulate matter on mortality in Europe and North America: results from the APHENA study. Environ Health Perspect. 2008;116(11):1480.

17. Stafoggia M, Samoli E, Alessandrini E, Cadum E, Ostro B, Berti G, et al. Short-term associations between fine and coarse particulate matter and hospitalizations in Southern Europe: results from the MED-PARTICLES project. Environ Health Perspect (Online). 2013;121(9):1026.

18. Organization WH. Review of evidence on health aspects of air pollution-REVIHAAP Project. First Results. 2013:33.

19. Lu F, Zhou L, Xu Y, Zheng T, Guo Y, Wellenius GA, et al. Shortterm effects of air pollution on daily mortality and years of life lost in Nanjing, China. Sci Total Environ. 2015;536:123-9.

20. Zeka A, Zanobetti A, Schwartz J. Individual-level modifiers of the effects of particulate matter on daily mortality. Am J Epidemiol. 2006;163(9):849-59.

21. Kan H, London SJ, Chen G, Zhang Y, Song G, Zhao N, et al. Season, sex, age, and education as modifiers of the effects of outdoor air pollution on daily mortality in Shanghai, China: The Public Health and Air Pollution in Asia (PAPA) Study. Environ Health Perspect. 2008;116(9):1183.

22. Dastoorpoor M, Idani E, Khanjani N, Goudarzi G, Bahrampour A. Relationship Between Air Pollution, Weather, Traffic, and TrafficRelated Mortality. Trauma Mon. 2016;21(4).

23. Maleki H, Sorooshian A, Goudarzi G, Nikfal A, Baneshi MM. Temporal profile of PM 10 and associated health effects in one of the most polluted cities of the world (Ahvaz, Iran) between 2009 and 2014. Aeolian Res. 2016;22:135-40.

24. Idani E, Dastoorpoor M, Goudarzi G, Khanjani N. Severe Outbreaks of Respiratory Syndromes Following Autumn Rainfall in Khuzestan, Iran. Arch Iran Med. 2016;19(12):884.

25. Masoumi K, Haddadzadeh Shoushtari M, Forouzan A, Asgari Darian A, Dastoorpoor M, Ebrahimzadeh P, et al. Rainfall-Associated Bronchospasm Epidemics: The Epidemiological Effects of Air Pollutants and Weather Variables. Can Respir J. 2017;2017(1-12).

26. Dastoorpoor M, Idani E, Goudarzi G, Khanjani N. Acute effects of air pollution on spontaneous abortion, premature delivery, and stillbirth in Ahvaz, Iran: a time-series study. Environ Sci Pollut Res. 2017.

27. Dastoorpoor M, Goudarzi G, Khanjani N, Idani E, Aghababaeian H, Bahrampour A. Lag time structure of cardiovascular deaths attributed to ambient air pollutants in Ahvaz, Iran, 2008-2015. Int J Occup Med Environ Health.2018.(InPress).
28. Goudarzi G, Geravandi S, Vosoughi M, javad Mohammadi M, sada Taghavirad S. Cardiovascular deaths related to Carbon monoxide Exposure in Ahvaz, Iran. IJHSE. 2014;1(3):126-31.

29. Goudarzi G, Geravandi S, Saeidimehr S, Mohammadi M, Vosoughi Niri M, Salmanzadeh S, et al. Estimation of health effects for PM10 exposure using of Air Q model in Ahvaz City during 2009. Iran J Health Environ. 2015;8(1):117-26.

30. Goudarzi G, Mohammadi M, Ahmadi Angali K, Mohammadi B, Soleimani Z, Babaei A, et al. Estimation of number of cardiovascular death, myocardial infarction and Chronic Obstructive Pulmonary Disease (COPD) from NO2 exposure using Air Q Model in Ahvaz city during 2009. Iran J Health Environ. 2013;6(1):91-102.

31. Dadbakhsh M, Khanjani N, Bahrampour A, Haghighi PS. Death from respiratory diseases and temperature in Shiraz, Iran (2006-2011). Int J Biometeorol. 2016:1-8.

32. Khanjani N, Bahrampour A. Temperature and cardiovascular and respiratory mortality in desert climate. A case study of Kerman, Iran. Iranian J Environ Health Sci Eng. 2013;10(1):1

33. Mills NL, Donaldson K, Hadoke PW, Boon NA, MacNee W, Cassee FR, et al. Adverse cardiovascular effects of air pollution. Nat Clin Pract Cardiovasc Med. 2009;6(1):36-44.

34. Vahedian M, Khanjani N, Mirzaee M, Koolivand A. Associations of short-term exposure to air pollution with respiratory hospital admissions in Arak, Iran. J Environ Health Sci Eng. 2017;15(1):17.

35. Hashemi S, Khanjani N, Soltaninejad Y, Momenzadeh R. Air Pollution and Cardiovascular Mortality in Kerman from 2006 to 2011. American Journal of Cardiovascular Disease Research. 2014;2(2):27-30

36. Vahedian M, Khanjani N, Mirzaee M, Koolivand A. Ambient air pollution and daily hospital admissions for cardiovascular diseases in Arak, Iran. ARYA Atheroscler. 2017;13(3):117-34.

37. Ghorbanian J. Dust Storms and Weighting Criteria and Prevention The Case of Hoorolazim (Text in Persian). Geography. 2015;13(47):269-86

38. Sahsavani A, Yarahmadi M, Mesdaghinia A, Younesyan M, Jaafarzadeh N, Naeemabadi A, et al. Analysis of dust storms entering Iran with emphasis on Khuzestan Province. Hakim Res J. 2012;3:192-202.

39. Liang W-M, Wei H-Y, Kuo H-W. Association between daily mortality from respiratory and cardiovascular diseases and air pollution in Taiwan. Environ Res. 2009;109(1):51-8.

40. Lipsett MJ, Ostro BD, Reynolds P, Goldberg D, Hertz A, Jerrett M, et al. Long-term exposure to air pollution and cardiorespiratory disease in the California teachers study cohort. Am J Respir Crit Care Med. 2011;184(7):828-35.

41. Jerrett M, Finkelstein MM, Brook JR, Arain MA, Kanaroglou P, Stieb DM, et al. A cohort study of traffic-related air pollution and mortality in Toronto, Ontario, Canada. Environ Health Perspect. 2009;117(5):772-7

42. Wong T, Tam W, Yu T, Wong A. Associations between daily mortalities from respiratory and cardiovascular diseases and air pollution in Hong Kong, China. Occup Environ Med. 2002;59(1):30-5

43. Stafoggia M, Forastiere F, Faustini A, Biggeri A, Bisanti L, Cadum E, et al. Susceptibility factors to ozone-related mortality: a population-based case-crossover analysis. Am J Respir Crit Care Med. 2010;182(3):376-84.

44. Hales S, Blakely T, Woodward A. Air pollution and mortality in New Zealand: cohort study. J Epidemiol Community Health. 2010:jech. 2010.112490.

45. Abbey DE, Nishino N, McDonnell WF, Burchette RJ, Knutsen SF, Lawrence Beeson W, et al. Long-term inhalable particles and other air pollutants related to mortality in nonsmokers. Am J Respir Crit Care Med. 1999;159(2):373-82.

46. Qian Z, He Q, Lin H-M, Kong L, Liao D, Dan J, et al. Association of daily cause-specific mortality with ambient particle air pollution in Wuhan, China. Environ Res. 2007;105(3):380-9.

47. Jonadi Jafarii A, Zohor A RR, Malekafzali S SA. Estimated number of deaths attributable to air pollution in Tehran particles Vtnfsy Heart(2006). Medicine and purification. 2009;74-75:37-47.

48. Braga AL, Zanobetti A, Schwartz J. The effect of weather on respiratory and cardiovascular deaths in 12 US cities. Environ Health Perspect. 2002;110(9):859. 
49. Kim H, Kim Y, Hong Y-C. The lag-effect pattern in the relationship of particulate air pollution to daily mortality in Seoul, Korea. Int J Biometeorol. 2003;48(1):25-30.

50. Zeka A, Zanobetti A, Schwartz J. Short term effects of particulate matter on cause specific mortality: effects of lags and modification by city characteristics. Occup Environ Med. 2005;62(10):718-25.

51. Zanobetti A, Schwartz J, Samoli E, Gryparis A, Touloumi G, Peacock $\mathrm{J}$, et al. The temporal pattern of respiratory and heart disease mortality in response to air pollution. Environ Health Perspect. 2003;111(9):1188-93.

52. Goodman PG, Dockery DW, Clancy L. Cause-specific mortality and the extended effects of particulate pollution and temperature exposure. Environ Health Perspect. 2004;112(2):179.

53. Cesaroni G, Badaloni C, Gariazzo C, Stafoggia M, Sozzi R, Davoli $\mathrm{M}$, et al. Long-term exposure to urban air pollution and mortality in a cohort of more than a million adults in Rome. Environ Health Perspect. 2013;121(3):324.

54. Beelen R, Hoek G, van Den Brandt PA, Goldbohm RA, Fischer P, Schouten LJ, et al. Long-term effects of traffic-related air pollution on mortality in a Dutch cohort (NLCS-AIR study). Environ Health Perspect. 2008;116(2):196.

55. Gehring U, Heinrich J, Krämer U, Grote V, Hochadel M, Sugiri D, et al. Long-term exposure to ambient air pollution and cardiopulmonary mortality in women. Epidemiology. 2006;17(5):545-51.

56. Heinrich J, Thiering E, Rzehak P, Krämer U, Hochadel M, Rauchfuss $\mathrm{KM}$, et al. Long-term exposure to NO2 and PM10 and all-cause and cause-specific mortality in a prospective cohort of women. Occup Environ Med. 2012:oemed-2012-100876.

57. Dong G-H, Zhang P, Sun B, Zhang L, Chen X, Ma N, et al. Longterm exposure to ambient air pollution and respiratory disease mortality in Shenyang, China: a 12-year population-based retrospective cohort study. Respiration. 2011;84(5):360-8.

58. Yorifuji T, Kashima S, Tsuda T, Takao S, Suzuki E, Doi H, et al. Long-term exposure to traffic-related air pollution and mortality in Shizuoka, Japan. Occup Environ Med. 2010;67(2):111-7.

59. Filleul L, Rondeau V, Vandentorren S, Le Moual N, Cantagrel A, Annesi-Maesano I, et al. Twenty five year mortality and air pollution: results from the French PAARC survey. Occup Environ Med. 2005;62(7):453-60.

60. Kelly FJ, Blomberg A, Frew A, Holgate ST, Sandstrom T, Antioxidant kinetics in lung lavage fluid following exposure of humans to nitrogen dioxide. Am J Respir Crit Care Med. 1996;154(6):1700-5.

61. Blomberg A, Krishna MT, Bocchino V, Biscione GL, Shute JK, Kelly FJ, et al. The inflammatory effects of $2 \mathrm{ppm} \mathrm{NO} 2$ on the airways of healthy subjects. Am J Respir Crit Care Med. 1997;156(2):418-24.

62. Folinsbee L. Does nitrogen dioxide exposure increase airways responsiveness?. Toxicol Ind Health. 1991;8(5):273-83.

63. Morrow PE, Utell MJ, Bauer MA, Smeglin AM, Frampton MW, Cox $\mathrm{C}$, et al. Pulmonary performance of elderly normal subjects and subjects with chronic obstructive pulmonary disease exposed to 0.3 ppm nitrogen dioxide. Am J Respir Crit Care Med. 1992;145(2):291-300.

64. Barck C, Lundahl J, Hallden G, Bylin G. Brief exposures to NO 2 augment the allergic inflammation in asthmatics. Environ Res. 2005;97(1):58-66.

65. Mölter A, Agius R, de Vocht F, Lindley S, Gerrard W, Custovic A, et al. Effects of long-term exposure to PM10 and NO2 on asthma and wheeze in a prospective birth cohort. J Epidemiol Community Health. 2013:jech-2013-202681.

66. Gholizadeh M, Farajzadeh M, Darand M. The correlation between air pollution and human mortality in Tehran. Hakim Research Journal. 2009;12(2):65-71.

67. Mohammadi H, Ovasierad H. Investigate the relationship between atmospheric elements and pollutants $\mathrm{CO}$ on mortality from respiratory diseases in people under 12 years of Tehran. J Geog. 2010:33-55.

68. Zhang J, Song H, Tong S, Li L, Liu B, Wang L. Ambient sulfate concentration and chronic disease mortality in Beijing. Sci Total Environ. 2000;262(1):63-71.

69. Arbex MA, Santos UdP, Martins LC, Saldiva PHN, Pereira LAA, Braga ALF. Air pollution and the respiratory system. J Bras Pneumol. 2012;38(5):643-55.
70. Künzli N, Perez L, Rapp R. Air quality and health. Lausanne: European Respiratory Society. 2010.

71. Samet J, Dominici F, Zeger S, Schwartz J, Dockery D. The National Morbidity, Mortality, and Air Pollution Study. Part I: Methods and methodologic issues. Res Rep Health Eff Inst. 2000 (94 Pt 1):5-14; discussion 75-84 